Crime, Histoire \& Sociétés / Crime, History \& Societies

Vol. 21, n² | 2017

L'histoire de la criminalité et de la justice pénale : propositions de recherche pour le $21^{\mathrm{e}}$ siècle

\title{
Future Trends in Historical Research on Policing: Towards Global and Interdisciplinary Perspectives
}

Anja Johansen

\section{(2) OpenEdition \\ Journals}

Electronic version

URL: https://journals.openedition.org/chs/1826

DOI: $10.4000 /$ chs. 1826

ISSN: 1663-4837

\section{Publisher}

Librairie Droz

\section{Printed version}

Date of publication: 31 December 2017

Number of pages: 113-121

ISSN: $1422-0857$

\section{Electronic reference}

Anja Johansen, "Future Trends in Historical Research on Policing: Towards Global and Interdisciplinary Perspectives", Crime, Histoire \& Sociétés / Crime, History \& Societies [Online], Vol. 21, $n^{\circ} 2$ | 2017, Online since 22 November 2018, connection on 21 September 2021. URL: http:// journals.openedition.org/chs/1826 ; DOI: https://doi.org/10.4000/chs.1826 


\title{
Future Trends in Historical Research on Policing: Towards Global and Interdisciplinary Perspectives
}

\author{
Anja Johansen
}

Cince the foundation of Crime, History \& Societies/Crime, Histoire \& Sociétés

$\checkmark$ twenty years ago historical studies of police organisations and policing have been among the core themes for our publication. The field developed from very timid beginnings in the late 1960s, when a few scholars from a variety of fields started to look at policing beyond traditional legal-institutional approaches ${ }^{1}$. From this point, a new generation of social historians and sociologists began studying police - and later gendarmerie forces - in their own right, not simply as a branch of the state or local government, but as organisations comprised of people with particular social backgrounds, cultural outlooks and interests that shape the dynamics around police forces, both internally and in relation to their political superiors and to the population. Looking at police from social and cultural perspectives generated new questions about on how policemen themselves understood their role and performed their professional duties. Over the past five decades historical and sociological scholarship on policing and police organisations has developed into a thriving field that has expanded in multiple directions. Historical studies now cover policing from the sixteenth century to the present, with some studies looking at forms of policing going further back in time to the antiquity and medieval era.

Because of the expansive and heterogeneous nature of the literature on policing, this review will focus on four themes, which are currently emerging as major themes or challenges that police scholars will have to address collectively in order to develop the field and create some links between the multiple aspects of this sprawling academic field: i) the policing of non-Western societies, past and present; ii) the development of global interpretations of the history of policing; iii) moves towards greater interdisciplinary conversations and exchange between police historians and sociologists, criminologists, anthropologist as well as political scientist and legal scholars; and iv) finally, further developments of theories of policing.

Critchley's A History of Police in England and Wales, 1900-1966 (1967) constitutes one of the last major works with a purely legal-institutional approach to police history. The same year we saw the publication of Roger Lane's ground-breaking historical study Policing the City. Boston 1822-1885 (1967), and the collection of essay "The Police: Six Sociological Essays", which included both Allan Silver's seminal sociological essay "The Demand for Order in Civil Society" (1967) and Jerome H. Skolnick's "Bureaucracy, Information and Social Control". 


\section{POLICING OF NON-WESTERN SOCIETIES}

Until recently, the studies available in English and French were mostly focused on the Western world, with an abundance of works focused on the US/Canada, numerous western European countries, and Australia. Currently, this overwhelming focus on the Western world is about to change. A brief survey of the literature published in English, French and German over the past three years on "policing", "police" or "gendarmerie" shows an increasing number of studies published in English - fewer in French and German - on police forces and policing of central and Eastern Europe, Latin America, Japan, China, India, and Africa ${ }^{2}$. While most of these works are social science studies on contemporary issues, there are also clear signs of this trend in historical studies.

Among police scholars - restricted as we are by language barriers - there is immense curiosity about non-Western forms of policing. We have become so familiar with forms of policing growing out of European and North American cultures, while our understanding of forms of policing in other parts of the world has been at best patchy, or simply non-existent. The recent trend in studies of colonial policing, testifies to the appetite for breaking new grounds. Despite a handful of seminal works in the 1980s and 1990s ${ }^{3}$, colonial policing long remained a neglected aspect of policing at least among the works available in English, French and German. This has changed dramatically over the past decade with the publication of important works on a broad range of imperial experiences with the works by scholars like Emmanuel Blanchard on French colonial policing, Marieke Bloembergen and Ellen Klinkers on Dutch colonial policing, Joël Glasman on German colonial policing, Georgina Sinclair and Martin Thomas on British colonial experiences. This interest can also be discerned from the increasing number of conferences and collective publications focused on colonial policing, not just British and French but also German, Dutch, Belgian and Danish colonial policing ${ }^{4}$. Most importantly the increasing number of non-Europeans in the field, who have access to non-European languages, are of immense value to our collective insights. The access to studying police history with inclusion of non-European voices also opens new questions about pre-colonial forms of policing and social control. This fusion of pre-colonial forms of policing with colonial policing also shaped postcolonial forms of policing, a multiplicity of hybrids with varying elements of precolonial, colonial and post-colonial features.

A brief overview of articles and books published on policing of non-Western societies in 2016 and 2017 (so far) shows the breath and variety of historical interests: Eynde (2016) and Newton (2016) both on the history of Kenyan Policing since 1957; Müller (2016) on police scandals in Transvaal 1886-1896; Watkins (2016) on the Egyptian secret police in Gaza 1948-1967; Harouvi (2016) on the Palestine police force under the British protectorate; Dölek-Sever (2017) on policing of Greeks and Armenians in Istanbul during the First World War; Shunsuke (2017) on censorship and the secret Japanese police under the Meiji and Taisho Period. In addition comes this non-exhaustive list of monographs published since 2010: Uranaka (2010) on policing of contemporary Japan; Matsuda (2011) on Korea under Japanese rule 1904-1919; Ho (2012) on Hong Kong under British rule 1842-1969; Basaran(2014) on the Ottoman Empire of the $19^{\text {th }}$ century.

3 Brogden (1987) and Anderson and Killingray $(1991,1992)$ on British colonial policing in general; Arnold (1986) and Das and Varma (1998) on policing of India; Clayton and Killingray (1989) and Deflem (1994) on Nyasaland on colonial policing in Africa.

4 Sinclair (2011); Denis and Denys (2012); Blanchard et al. (2017). 
Integrating non-European perspectives in our understanding provides some healthy and very welcome challenges and perspectives on current Western-centred interpretations: Do we actually fully understand policing in Western cultures before we have systematically compared it with forms of policing that were not rooted in Western cultural thinking? We need the kind of fundamental research on policing structures and police organisations in non-Western societies in order to properly conceptualise police organisations and policing.

\section{TOWARDS GLOBAL HISTORIES OF POLICING}

In coming years the history of policing will inevitably have to engage with some form of Global History perspective. Critics legitimately question whether global historical interpretations of policing are at all possible, but we can identify at least two very different strands of policing with global perspectives: one is the history of international police cooperation and the other is the comparison of national and sub-national experiences from across the globe. Like the history of colonial policing, the history of international police cooperation constituted a very marginal concern with a handful of studies from the 1980s and $1990 \mathrm{~s}^{5}$. However, since the turn of the millennium with the War on Terror after $9 / 11$ and increasing concerns about international crime, there has been a notable upsurge in research on the historical origins of internationalisation and globalisation of police cooperation ${ }^{6}$.

A global integration of research on policing of jurisdictions from across the world will inevitably challenge existing frameworks of interpretation and enable us to connect existing research (based on national and local studies) with global interpretations of policing of the recent and deep past. Such re-conceptualisations could take at least three distinctly dissimilar forms, which are not mutually exclusive: The first is the drawing out of connections between experiences of policing from across the globe over the past three centuries at least. Although highly ambitious, and only partly possible due to records for many areas being poor or non-existent until the very recent past, this is one of the goals that we have to aim for in order to move beyond Western-centred perspectives.

The inclusion of police studies from non-Western areas and from past societies also constitute an essential element in identifying which features of policing appear in relation to all - or most - types of police organisation and to the act of "policing" (tendencies towards organisational insulation; policing at the edges or beyond the boundaries of the law; difficulties of preventing excessive use of force; conflictual relationships with the population or sections of the population; difficulties of civilian governments and courts to effectively hold police to account, individually or collective). Only when we have identified the factors which seem to be inherent albeit to various degrees - can we properly identify and analyse the features shaped by specific legal-institutional frameworks, particular regimes and political cultures.

Another area ripe for re-conceptualisation in relation to police history would be a re-thinking of the conceptual dichotomy of "democratic" versus "non-democratic"

Jensen (1981); Fijnaut and Hermans (1987); Liang (1992); Nadelmann (1993).

6 Deflem (2002); Knepper (2009, 2011); Fijnaut (2016). 
societies. This distinction underlies not only a lot of social science scholarship on policing ${ }^{7}$, explicitly or implicitly, but has also influenced historical interpretations of policing of the nineteenth and twentieth centuries, building on Liang's linking of police modernity to democratisation ${ }^{8}$. Yet, analysing policing through this dichotomy often precludes a proper understanding of the nature of policing in pre-democratic and democratising societies. The dilemma for police historians is this: that policing in even solidly democratic countries frequently violates the fundamental characteristics of supposed "democratic policing". Conversely, policing in countries with few or no democratic credentials - often pre-democratic societies - sometimes did meet the criteria for policing "democratically" in some form or other. While the ethical principles behind what is currently termed "democratic policing" are laudable and should be developed, the term "democratic policing" itself seems counterproductive as an interpretational category.

In order to bridge the traditional opposition between "policing of the West" and "policing of the Rest" a re-think of the impact of democratisation and democratic political institutions on policing is necessary for two reasons: insisting on opposition between Western and non-Western policing makes it difficult to include the experiences of countries whose recent history has been characterised by authoritarian, dictatorial, failed-state or other forms of non-democratic experiences and cast these countries as the eternal "other". This easily leads us to underestimate the similarities with policing in countries without such legacies. Rather than conceptualising "democratic policing" as a package, it would be fruitful to investigate each element within this concept and test it against policing in democratic, democratising and nondemocratic regimes, past and present.

Similarly, we also need to identify whether and how military organisations, private security firms and public non-police agencies such as public administration and social workers should be included in an overall concept of policing, as interpretational distinctions between civil/military or public/private has become less meaningful in the light of recent research on such forms of policing. In this respect, policing in the twenty first century seems to reflect patterns of policing in Europe before the rise of modern policing in the nineteenth century. Moreover, multiple studies on European gendarmerie forces and gendarmerie in colonial contexts have helped to break down the distinction, which has characterised interpretations of policing in Britain and Europe since the early nineteenth century, between gendarmerie-style police forces and civilian police forces. Gendarmerie forces have long been type cast as intrinsically "different" to civilian policing, yet much research on multiple types of gendarmerie forces increasingly cast doubt on this distinction as valid and fruitful for our understanding: Over the past fifty years there has been considerable convergence of military-organised forces with standards for civilian policing; at the same time, civilian police in many countries have become increasingly militarised due security scares about terrorism. The presence of armed police in public in Britain is a particularly stark example of this new development.

\footnotetext{
7 Originating with Reith (1943), David Bayley has developed current concept of "democratic policing" across many years $(1983,2006)$. Other influential police scholars like Robert Reiner (2010) and Peter Manning (2010) have also closely linked the idea of democratic political regime to a particular approach to policing.

$8 \quad$ Liang (1992, p.4).
} 
Breaking down the dichotomies democratic/non-democratic, civilian/military, public/private would help discover connections and parallels, which are currently rarely identified, such as when a random coincidence of conference presentations revealed completely unexpected similarities between my own research on nineteenthcentury Prussian policing and sociological studies on policing in twenty-first-century Mali.

\section{INTERDISCIPLINARY CONVERSATIONS AND EXCHANGES}

The third area that police historians need to further develop is their engagement with scholars working on policing from neighbouring fields: political science and law, sociology, criminology, anthropology and psychology. Bringing together insights from different disciplines has much to offer in term of allowing multifaceted, subtle analysis of the dynamics, power relations, boundaries, practices and motivations that shape both in the internal functioning police forces, but also the engagement between police and wider society.

This integration is beneficial for both social science studies of policing in the present and for historical studies of policing in the past: Social science research on contemporary policing can help police historians understand complex dynamics such as inter-organisational mechanisms, power relationships with superiors, conflicts and cooperation with the public, which are only partially documented in the past - or not at all. Without the insights from socio-cultural studies of contemporary policing, many factors of policing in the past can be difficult to make sense of due to often highly fragmented evidence that cannot be complemented through surveys and interviews.

On their side, police scholars working on contemporary policing can benefit from historical perspectives in order to contextualise current issues of policing, and also to avoid presenting present day problems around policing as if they are simply a product of modern social conditions or the consequences of particular social and political conditions of any given society. By obtaining a broader global and historical understanding of policing as a social, political and cultural phenomenon, it will be possible to distinguish more clearly between perennial features around policing that are caused by the particular function of an agency empowered by society to enforce laws and social norms rather than generated by any particular legal-institutional arrangements or social, political or cultural make-up. In addition, endeavours both by social scientists and police historians to develop typologies of police organisations and modelling different approaches to policing would be greatly strengthened once we have greater insights into policing across the world and into a distant past ${ }^{9}$. This is an area where the knowledge and insights from social scientists and police historians need to come together.

Bayley (1985, p.164-167); Emsley (2014, p.5-25). 


\section{TOWARDS THE DEVELOPMENT OF THEORIES OF POLICING}

The increasing diversity in police studies across time periods and geographical areas as well as disciplines involved makes it increasingly urgent to further develop theories of policing that form anchor points for the diverse interpretations emanating from the field. There are two particular areas that police scholars have wrestled with since the 1960s-1970s, which rather than having been clarified with the undertaking of more research have instead become more open and ambiguous ${ }^{10}$.

The first are definitions (we need to keep these in plural) of the object of police research: What constitutes a "police organisation" and what is "policing"? Definitions become increasingly urgent the more the field includes non-Western societies and move back in time beyond the sixteenth century, when modern concepts of police forces and policing become increasingly difficult to apply. Much of the problem about theorising policing lies in the fundamental difficulty of defining the object of study: whenever we think we know what we are talking about, we discover new aspects of policing that opens further questions about the boundaries of the field. On the other hand, the enforcement of law and social norms exists in all societies, and most police scholars instinctively recognise elements of policing when we see it, even in very different guises and in highly dissimilar cultural contexts. Due to the heterogeneous nature of organisations performing aspects of law-enforcement, order-maintenance, social control, crime prevention and crime fighting, the question remains open about which types of public, semi-public or private organisations should be included as exercising "policing" as one of their core activities.

Even when taking a narrow definition of policing and focusing exclusively on organisations that are designated as such, it is clear that these fulfil a highly diverse range of functions between law-enforcement, crime-fighting to civilian administration and social work. Moreover, the connections between different agencies performing some aspect of policing to the regime are also difficult to place on a formula. This became particularly clear with Brodeur's excellent book The Policing Web, which defined political police and secret services as part of core policing practices, whereas police scholars have tended to see such activities as outside the remit of "ordinary policing" as one of the defining feature of modern civilian policing ${ }^{11}$. At some point we need to develop some overarching concepts of police studies that can bring our disjoined knowledge and insights together, connecting multiple dots which are currently isolated or only tentatively connected.

The difficulties of defining the object of the study is linked to another key question concerning where the study of policing fits into the broad disciplinary matrix of social science. In the 1970s, the study of policing originally seemed a rather niche concern, tucked away as a sub-section of criminology, which was in turn a sub-section of sociology. In the light of the explosion of studies, with ever expanding geographical areas, extended time frames, and a proliferation of aspects coming under the heading of "policing", a debate has been opened by proponents of the so-called "new policescience" as to whether the study of policing should rightly be returned to the place occupied in the eighteenth-century Polizeywissenschaft, right at the heart of the study

10 Bordua (1967); Bittner (1970).

11 Brodeur (2010). 
of government ${ }^{12}$. The question is not merely academic. Just as the definition of the object of study, it reflects fundamental conceptions about the nature of policing, even if actual theorising on policing is still very much work in progress ${ }^{13}$.

\section{CONCLUSION}

Over the past fifty years of research on policing issues, past and present, we have barely scratched the surface. Studies in ever wider geographical areas across greater periods of time, revealing new insights have opened for new fields in need of scholarly investigations, contextualisation and comparison. It will be the task of future police scholars and historians to link these insights into interpretations of broader regions, continents and cross-continent experiences. At the same time, these new insights will inevitably affect our current understanding of policing of Western societies and challenge us to rethink existing interpretations, concepts and models. Crime, History \& Society/Crime, Histoire \& Sociétés has been at the forefront both of pioneering research into new areas of police history, of encouraging new generations of historians to engage with the subject and reaching out to scholars in neighbouring fields of social sciences. May it long continue!

Anja Johansen School of Humanities University of Dundee (UK) a.m.johansen@dundee.ac.uk

\section{BIBLIOGRAPHY}

Anderson, D. and Killingray, D. (Eds.) (1991) Policing the Empire: government, authority and control, 1830-1940, Manchester: Manchester University Press.

Anderson, D. and Killingray, D. (Eds.) (1992) Policing and decolonisation: Politics, nationalism and the police, 1917-1965, Manchester: Manchester University Press.

Arnold, D. (1986) Police power and colonial rule: Madras 1859-1947, Delhi: Oxford University Press.

Basaran, B. (2014) Selim III, Social Control and Policing in Istanbul at the End of the Eighteenth Century: Between Crisis and Order, Leiden: Brill.

Bayley, D. (1983) Accountability and Control of Police: Lessons for Britain, in Bennett, T. (Ed.), The Future of Policing, Cambridge: Cambridge University Press.

Bayley, D. (1985) Patterns of Policing: A comparative international analysis, New Brunswick: Rutgers University Press.

Bayley, D. (2006) Changing the Guard: Developing Democratic Policing Abroad, Oxford: Oxford University Press.

12 Neocleous (2006, p.21); Dodsworth (2008); for a critical appreciation see Reiner (2010).

13 Smith (2016); Loader (2014); Emsley (2013). 
Bittner, E. (1970) The Function of the Police in Modern Society, Washington D.C.: Government Printing Office.

Blanchard, E., Bloembergen, M. and Lauro, A. (Eds.) (2017) Policing in colonial Empires: Cases, Connections, Boundaries (1850-1970), Bruxelles: Peter Lang.

Bordua, D. (Ed.) (1967) The police: six sociological essays, New York: Wiley.

Brodeur, J.-P. (2010) The Policing Web, Oxford: Oxford University Press.

Brogden, M. (1987) The Emergence of the Police - The Colonial Dimension, British Journal of Criminology, 27, 1, p.4-14.

Clayton, A. and Killingray, D. (1989) Khaki and blue: military and police in British colonial Africa, Athens, Ohio: Ohio University Press.

Critchley, T. (1967) A History of Police in England and Wales, 1900-1966, London: Constable.

Das, D. and Varma, A. (1998) The armed police in the British colonial tradition: The Indian perspective, Policing: An International Journal of Police Strategies \& Management, 21, 2, p.354-367.

Deflem, M. (1994) Law Enforcement in British Colonial Africa: A comparative analysis of imperial policing in Nyasaland, the Gold Coast and Kenya, Police Studies, 17, 1, p.45-68.

Deflem, M. (2002) Policing the World: Historical Foundations of International Police Cooperation, Oxford: Oxford University Press.

Denis, V. and Denys, C. (Eds.) (2012) Polices de l'Empire, XVIII ${ }^{e}$-XIX ${ }^{e}$ siècles, Rennes: Presses Universitaire de Rennes.

Dodsworth, F. (2008) The Idea of Police in Eighteenth-Century England: Discipline, Reformation, Superintendence, ca. 1788-1800, Journal of the History of Ideas, 69, 4, p.583-604.

Dölek-Sever, D. (2017) Policing the "suspects": Ottoman Greeks and Armenians in Istanbul, 1914-18, London: Routledge.

Emsley, C. (2013) Peel's Principles, Police Principles, in Brown, J. (Ed.), The Future of Policing, London: Routledge.

Emsley, C. (2014) Policing the empire/Policing the metropole: Some thoughts on models and types, Crime, History \& Societies, 18, 2, p.5-25.

Eynde, O., van den (2016) Trickle-Down Ethic politics: Drunk and Absent in the Kenya Police Force (1957-1970), Papers from The Oxford Centre for the Study of African Economics, 21.

Fijnaut, C. (2016) The Containment of Organised Crime and Terrorism: Thirty-Five Years of Research on Police, Judicial and Administrative Cooperation, Leiden: Brill.

Fijnaut, C. and Hermans, R. (Eds.) (1987) Police Cooperation in Europe, Lochem: van den Brink.

Harouvi, E. (2016) Palestine Investigated: The Criminal Investigation Department of the Palestine Police Force, 1920-1948, Eastbourne: Sussex Academic Press.

Ho, L. (2012) Policing Hong Kong 1842-1969: Insiders' stories, Hong Kong: City University of Hong Kong Press.

Jensen, R. (1981) The International Anti-Anarchist Conference of 1898 and the Origins of Interpol, Journal of Contemporary History, 16, p.323-347.

Knepper, P. (2009) The Invention of International Crime: A Global Issue in the Making, 1881 1914, Basingstoke: Palgrave Macmillan. 
Knepper, P. (2011) International Crime in the Twentieth Century: The League of Nations Era, 1919-1939, Basingstoke: Palgrave Macmillan.

Lane, R. (1967) Policing the City. Boston 1822-1885, Cambridge, Mass.: Harvard University Press.

Liang, H.-H. (1992) The Rise of Modern Police and the European State System from Metternich to the Second World War, Cambridge: Cambridge University Press.

Loader, I. (2014) In Search of Civic Policing: Recasting the "Peelian" Principles, Criminal Law and Philosophy, 10, 3, p.427-440.

Manning, P. (2010) Democratic Policing in a Changing World, Boulder: Paradigm Publishers.

Matsuda, T. (2011) Governance and policing of colonial Korea, 1904-1919, Kyoto: International Research Centre for Japanese Studies.

Müller, C. (2016) The Greatest State Scandal: Personality, Power and the South African Republic Police, 1886-1896, South African Historical Journal, 68, 1, p.13-30.

Nadelmann, E. (1993) Cops across Borders: The Internationalisation of US Criminal Law Enforcement, Pennsylvania: Pennsylvania State University Press.

Neocleous, M. (2006) Theoretical foundations of the "New Police Science", in Dubber, M. and Valverde, M. (Eds.), The New Police Science: The Police Power in domestic and international governance, Stanford: Stanford University Press.

Newton, J. (2016) A Living History of the Kenya Police, Leighton Buzzard: The Kenya Police Association.

Reiner, R. (2010) The Politics of the Police (4th ed), Oxford: Oxford University Press.

Reith, C. (1943) British Police and the Democratic Ideal, Oxford: Oxford University Press.

Shunsuke, N. (2017) Control of the Secret Information and the Publication Police in the Meiji and Taisho Period, Nihon shi kenkyu, 653, p.38-66.

Silver, A. (1967) The Demand for Order in Civil Society: a Review of Some Themes in the History of Urban Crime, Police and Riot, in Bordeau, D. (Ed.), The Police: Six Sociological Essays, New York: Wiley.

Sinclair, G. (Ed.) (2011) Globalising British Policing, Aldershot: Ashgate.

Skolnick, J.H. (1967) Bureaucracy, Information and Social Control, in Bordeau, D. (Ed.), The Police: Six Sociological Essays, New York: Wiley.

Smith, W. (2016) Law and (Global) Order: Towards a Theory of Cosmopolitan Policing, Critical Horizons, 17, 1, p.135-148.

Uranaka, C. (2010) Police et contrôle social au Japon, Paris: L'Harmattan.

Watkins, J. (2016) Police encounters: security and surveillance in Gaza under Egyptian rule, Policing and Society, 26, 6, p.729-733. 